\title{
Attenuation of Salt-Loading Induced Cardiomegaly and Dyslipidemia in Wistar Rats by Aqueous Leaf Extract of Chromolaena odorata
}

\author{
Jude C. Ikewuchi*, Catherine C. Ikewuchi, Mercy O. Ifeanacho
}

Department of Biochemistry, Faculty of Chemical Sciences, College of Natural and Applied Sciences, University of Port Harcourt, Port Harcourt, Nigeria.

Email: *ecoli240733@yahoo.com

Received December $9^{\text {th }}, 2013$; revised January $9^{\text {th }}, 2014$; accepted January $21^{\text {st }}, 2014$

Copyright (C) 2014 Jude C. Ikewuchi et al. This is an open access article distributed under the Creative Commons Attribution License, which permits unrestricted use, distribution, and reproduction in any medium, provided the original work is properly cited. In accordance of the Creative Commons Attribution License all Copyrights (C) 2014 are reserved for SCIRP and the owner of the intellectual property Jude C. Ikewuchi et al. All Copyright (C 2014 are guarded by law and by SCIRP as a guardian.

\section{ABSTRACT}

The effect of aqueous extract of the leaves of Chromolaena odorata on body weight, organ sizes, lipid profiles and atherogenic indices was investigated in normal and sub-chronic salt-loaded rats. The normal and treatment control groups were fed $\mathbf{1 0 0 \%}$ of commercial feed, while the test control, reference and test treatment groups received an $8 \%$ salt-loaded diet. The extract (at 100 and $200 \mathrm{mg} / \mathrm{kg}$ body weight) and moduretics (at $1 \mathrm{mg} / \mathrm{kg}$ body weight) were orally administered daily. The normal and test control groups orally received appropriate volumes of water. The extract was screened for bioactive components using gas chromatography-coupled-flame ionization detector. The main glycosides, saponins, allicins, alkaloids, benzoic acid derivatives, terpenes and lignans detected were arbutin, avenacin B-1 (and avenacin A-1), diallyl thiosulphinate, lupanine, ferulic acid (and vanillic acid), limonene and retusin, respectively. Compared to test control, the extract dose-dependently, significantly (P $<\mathbf{0 . 0 5}$ ) lowered the heart size, plasma levels of triglyceride, total density lipoprotein, very low density lipoprotein, low density lipoprotein and non-high density lipoprotein cholesterol and atherogenic indices (cardiac risk ratio, atherogenic coefficient and atherogenic index of plasma). It also significantly increased plasma high density lipoprotein level. These results suggest a protective mechanism of the extract against hypertension induced cardiomegaly and dyslipidemia, thus suggesting that this may underlie its antihypertensive action.

\section{KEYWORDS}

Chromolaena odorata; Salt-Loading; Heart Size; Lipid Profile and Atherogenic Indices; Phytochemicals

\section{Introduction}

Dyslipidemia and cardiomegaly or cardiac hypertrophy often accompany hypertension and are among the risk factors for the development of cardiovascular disease $[1,2]$. Dyslipidemia, a disorder of lipoprotein metabolism in the form of either lipoprotein overproduction or deficiency, may be expressed as increased serum total cholesterol, low density lipoprotein cholesterol and/or triglycerides, a decrease in high density lipoprotein cholesterol concentration, or various combinations of these [3]. It usually results in altered membrane micro-viscosity,

\footnotetext{
"Corresponding author.
}

with the concomitant modifications of membrane properties [4], which, in cells participating in cardiovascular regulation, might be a part of pathogenetic mechanisms responsible for chronic elevation of blood pressure [5] and alterations in the vascular system leading to vessel damage [6]. The lowering of cholesterol concentrations in individuals at high risk of cardiovascular disease improves outcome [7], therefore, any pharmacological intervention that improves or normalizes abnormal lipid metabolism may be useful for reducing the risk of cardiovascular complications in the hypertensive.

Cardiomegaly refers to the enlargement of the heart. It is caused by an increased load imposed on the left ven- 
tricle and to intense neurohumoral activation [8]. It is related to endothelial dysfunction and associated with increased prevalence of stroke, chronic renal failure, ventricular dysfunction, ventricular arrhythmias, coronary disease and sudden death [9]. In fact, left ventricular hypertrophy is a powerful predictor of cardiovascular morbidity and mortality [10]. Several pharmacological, hemodynamic and non-hemodynamic factors are able to induce, reverse and prevent left ventricular hypertrophy [11], interstitial fibrosis and the progression of atherosclerotic effects [12], and anti-hypertensive drugs induce various degrees of hypertrophic regression [9]. Many lipid lowering therapies have been reported to decrease left ventricular hypertrophy [13]. So, it is ideal to have a medication which can control blood pressure while moderating the lipid profile and attenuating cardiac hypertrophy.

There is currently a tendency towards the use of natural products [14] or traditional medicine, probably due to the fact that it is perceived to be a cheaper means of treatment, and exists in every continent of the globe and in every cultural area of the world [15]. Many plants are currently used in traditional health care for the management of hypertension. One of such plants is Chromolaena odorata (family Asteraceae) commonly called siam weed [16], a native of South and Central America, but presently found throughout the tropics [17]. Ikewuchi et al. [18] investigated the hypotensive activity of the leaves. However, the mechanical and biochemical impact of this hypotensive activity is yet to be clearly understood. Consequent upon this, the present study undertook the investigation of the effect of aqueous extract of the leaves on the body weight, organ sizes, lipid profiles and atherogenic indices of normal and sub-chronic salt-loaded Wistar rats.

\section{Materials and Methods}

\subsection{Plant Collection and Preparation of Extract}

Samples of Chromolaena odorata plants (Figure 1) were collected from within the Abuja campus of the University of Port Harcourt, Nigeria. Their identity was confirmed by Dr Michael C. Dike of Taxonomy Unit, Department of Forestry and Environmental Management, Michael Okpara University of Agriculture, Umudike, Abia State; and Mr John Ibe, the Herbarium Manager of the Forestry Department, National Root Crops Research Institute, Umuahia. The leaves were removed, cleaned of soil, oven dried at $55^{\circ} \mathrm{C}$ and ground into powder. A known weight ( $400 \mathrm{~g}$ ) of the powder was soaked in $1.5 \mathrm{~L}$ of boiled, hot distilled water for $12 \mathrm{~h}$, after which the resultant mixture was filtered through cotton wool, and the filtrate (aqueous extract) was stored in the refrigerator

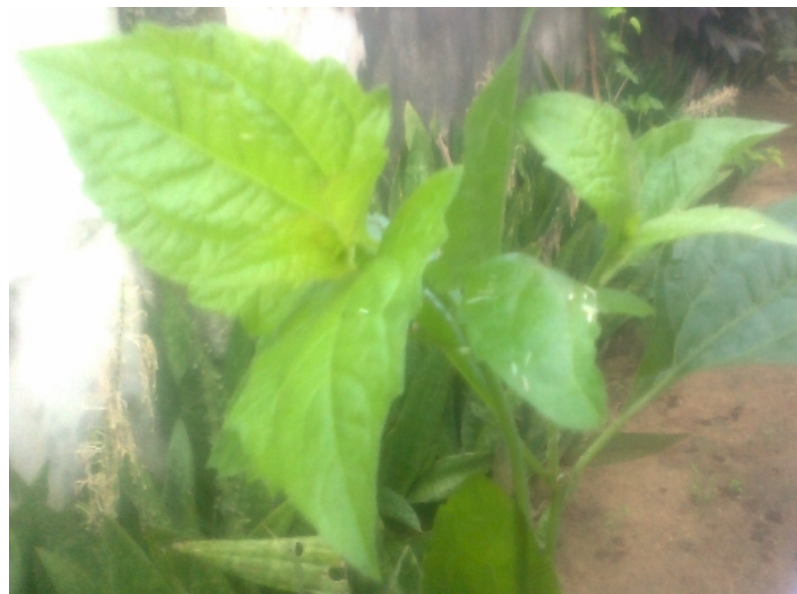

Figure 1. Chromolaena odorata.

for subsequent use. A known volume $(600 \mathrm{~mL})$ of this extract was evaporated to dryness, and the weight of the residue used to determine its concentration, which was in turn used to compute the dose of administration of the extract. The resultant residue of the crude aqueous extract was used for the phytochemical study.

\subsection{Determination of Phytochemical Profile}

\subsubsection{General Experimental Procedures}

Gas chromatography was carried out at Multi Environmental Management Consultants Limited, Igbe Road, Ikorodu, Lagos, with a Hewlett Packard HP 6890, gas chromatograph, fitted with flame ionization detector, powered with HP Chemstation Rev. A 09.01 (1206) software, to identify and quantify compounds. Standard solutions were prepared in methanol for alkaloids, allicins and benzoic acid derivatives; acetone for lignans; methylene chloride for terpenes; ethanol for glycosides and saponins. The linearity of the dependence of response on concentration was verified by regression analysis. Identification was based on comparison of retention times and spectral data with standards. Quantification was performed by establishing calibration curves for each compound determined, using the standards.

\subsubsection{Assay of Glycosides' Profile}

They were extracted as reported by Oluwaniyi and Ibiyemi [19]. The extract was subjected to gas chromatography on a capillary DB-225MS column $(30 \mathrm{~m} \times 0.25$ $\mathrm{mm} \times 0.25 \mu \mathrm{m}$ film thickness). The inlet and detection temperatures were $250^{\circ} \mathrm{C}$ and $320^{\circ} \mathrm{C}$. Split injection (split ratio of 20:1) was adopted. The carrier gas was nitrogen. The hydrogen and compressed air pressures were 1.97 and $2.81 \mathrm{~kg} / \mathrm{cm}^{2}$. The oven was programmed initially at $60^{\circ} \mathrm{C}$ for $5 \mathrm{~min}$, ramped at $12^{\circ} \mathrm{C} / \mathrm{min}$ for $18 \mathrm{~min}$, before ramping again at $15^{\circ} \mathrm{C} / \mathrm{min}$ for $5 \mathrm{~min}$. 


\subsubsection{Assay of Saponins' Profile}

The extraction was carried out as reported by Guo et al. [20]. The extract was subjected to gas chromatography on a capillary DB-225MS column $(30 \mathrm{~m} \times 0.25 \mathrm{~mm} \times$ $0.25 \mu \mathrm{m}$ film thickness). The inlet and detection temperatures were $250^{\circ} \mathrm{C}$ and $320^{\circ} \mathrm{C}$. Split injection (split ratio of 20:1) was adopted. The carrier gas was nitrogen. The hydrogen and compressed air pressures were 1.97 and $2.81 \mathrm{~kg} / \mathrm{cm}^{2}$. The oven was programmed initially at $60^{\circ} \mathrm{C}$ for $5 \mathrm{~min}$, ramped at $12^{\circ} \mathrm{C} / \mathrm{min}$ for $18 \mathrm{~min}$, before ramping again at $15^{\circ} \mathrm{C} / \mathrm{min}$ for $5 \mathrm{~min}$.

\subsubsection{Assay of Allicins' Profile}

The extraction was carried out as reported by Roy et al. [21]. The extract was subjected to gas chromatography on a capillary DB-5MS column $(30 \mathrm{~m} \times 0.32 \mathrm{~mm} \times 0.25$ $\mu \mathrm{m}$ film thickness). Injector and detector temperatures were $220^{\circ} \mathrm{C}$ and $250^{\circ} \mathrm{C}$. Split injection (split ratio of 20:1) was adopted. The carrier gas was helium, at a flow rate of $1.0 \mathrm{~mL} / \mathrm{min}$. The hydrogen and compressed air pressures were 1.55 and $1.97 \mathrm{~kg} / \mathrm{cm}^{2}$. The column was held initially at $110^{\circ} \mathrm{C}$ for $2 \mathrm{~min}$ and then increased at $5^{\circ} \mathrm{C} / \mathrm{min}$ up to $280^{\circ} \mathrm{C}$.

\subsubsection{Assay of Alkaloids' Profile}

The extraction was carried out as reported by Tram et al. [22], and the resulting extract was subjected to gas chromatography on a capillary DB-5MS column (30 m $\times$ $0.25 \mathrm{~mm} \times 0.25 \mu \mathrm{m}$ film thickness). The inlet and detection temperatures were $250^{\circ} \mathrm{C}$ and $320^{\circ} \mathrm{C}$. Split injection (split ratio of 20:1) was adopted. The carrier gas was nitrogen. The hydrogen and compressed air pressures were 1.97 and $2.67 \mathrm{~kg} / \mathrm{cm}^{2}$. The oven was programmed initially at $60^{\circ} \mathrm{C}$ for $5 \mathrm{~min}$, ramped at $10^{\circ} \mathrm{C} / \mathrm{min}$ for 20 min, before ramping again at $15^{\circ} \mathrm{C} / \mathrm{min}$ for $4 \mathrm{~min}$.

\subsubsection{Assay of Terpenes' Profile}

The extraction was carried out as reported by Ortan et al. [23]. The extract was subjected to gas chromatography on a capillary HP 5MS Column $(30 \mathrm{~m} \times 0.25 \mathrm{~mm} \times 0.25$ $\mu \mathrm{m}$ film thickness). The inlet and detection temperatures were $150^{\circ} \mathrm{C}$ and $300^{\circ} \mathrm{C}$. Split injection (split ratio of 20:1) was adopted. The carrier gas was hydrogen, at a flow rate of $1.0 \mathrm{~mL} / \mathrm{min}$. The hydrogen and compressed air pressures were 1.55 and $1.97 \mathrm{~kg} / \mathrm{cm}^{2}$. The oven was programmed initially at $40^{\circ} \mathrm{C}$, ramped at $5^{\circ} \mathrm{C} / \mathrm{min}$ to $200^{\circ} \mathrm{C}$, and ran at $200^{\circ} \mathrm{C}$ for $2 \mathrm{~min}$.

\subsubsection{Assay of Benzoic Acid Derivatives' Profile}

The extraction was carried out as reported by Ndoumou et al. [24]. The extract was subjected to gas chromatography on a capillary HP 1 column $(30 \mathrm{~m} \times 0.25 \mathrm{~mm} \times$ $0.25 \mu \mathrm{m}$ film thickness). The inlet and detection temper- atures were $250^{\circ} \mathrm{C}$ and $320^{\circ} \mathrm{C}$. Split injection (split ratio of 20:1) was adopted. The carrier gas was nitrogen, at a pressure of $2.11 \mathrm{~kg} / \mathrm{cm}^{2}$. The hydrogen and compressed air pressures were 1.97 and $2.25 \mathrm{~kg} / \mathrm{cm}^{2}$. The oven was programmed initially at $60^{\circ} \mathrm{C}$ for 5 min, ramped at $15^{\circ} \mathrm{C} / \mathrm{min}$ for $15 \mathrm{~min}$, maintained for $1 \mathrm{~min}$, before ramping again at $10^{\circ} \mathrm{C} / \mathrm{min}$ for $4 \mathrm{~min}$.

\subsubsection{Assay of Lignans' Profile}

The extraction was carried out as reported by Chapman et al. [25]. The extract was subjected to gas chromatography on a ZP-5 column $(30 \mathrm{~m} \times 0.32 \mathrm{~mm} \times 0.25 \mu \mathrm{m}$ film thickness). One microliter of sample was injected. The initial oven temperature was $40^{\circ} \mathrm{C}$, the injector and transfer line temperatures were $250^{\circ} \mathrm{C}$ and $280^{\circ} \mathrm{C}$. A solvent delay of $2.00 \mathrm{~min}$ was followed by ramping at $10^{\circ} \mathrm{C} / \mathrm{min}$ to a final temperature of $230^{\circ} \mathrm{C}$ and held for $1.00 \mathrm{~min}$.

\subsection{Bioassay}

\subsubsection{Experimental Design for the Bioassay}

Wistar albino rats (180 - $210 \mathrm{~g}$ at the start of the study) were collected from the animal house of the Department of Physiology, University of Nigeria, Enugu Campus. Studies were conducted in compliance with applicable laws and regulations for handling experimental animals. The rats were weighed and sorted into seven groups (Table 1) of five animals each, so that their average weights were approximately equal. The animals were housed in plastic cages. After a 1-week acclimatization period on guinea growers mash (Port Harcourt Flour Mills, Port Harcourt, Nigeria), they were weighed, and the experiment was commenced. Hypertension was induced by giving $8 \%$ salt-loaded feed for six weeks, to the appropriate rats. The $8 \%$ salt-loaded regimen was adopted from Ikewuchi et al. [18] and Obiefuna et al. [26]. At the end

Table 1. Experimental design for the salt-loading.

\begin{tabular}{|c|c|c|}
\hline $\mathbf{S} / \mathbf{N}$ & ID & Treatment \\
\hline 1 & Normal & Normal feed and water \\
\hline 2 & Test control & $8 \%$ salt-loaded feed and water \\
\hline 3 & Reference & $\begin{array}{l}8 \% \text { salt-loaded feed and moduretic } \\
\text { ( } 0.1 \mathrm{mg} / \mathrm{kg} \text { body weight })\end{array}$ \\
\hline 4 & Treatment I & $\begin{array}{l}\text { 8\% salt-loaded feed and extract } \\
\text { (100 mg/kg body weight) }\end{array}$ \\
\hline 5 & Treatment II & $\begin{array}{l}\text { 8\% salt-loaded feed and extract } \\
\text { ( } 200 \mathrm{mg} / \mathrm{kg} \text { body weight) }\end{array}$ \\
\hline 6 & Treatment control I & $\begin{array}{l}\text { Normal feed and extract } \\
\text { (100 mg/kg body weight) }\end{array}$ \\
\hline 7 & Treatment control II & $\begin{array}{l}\text { Normal feed and extract } \\
\text { (200 mg/kg body weight) }\end{array}$ \\
\hline
\end{tabular}


of six weeks, they were again weighed, before commencing the administration of the extract. The Moditen $^{\mathrm{TM}}$ (amyloride hydrochloride-hydrochlorothiazide; product of Greenfield Pharmaceutical Co. Ltd., Jiang Su Province, China) and the extract were administered daily by intra-gastric gavages, for ten days. The dosage of administration of the extract was adopted from Ikewuchi et al. [18]. The animals were allowed food and water ad libitum. At the end of the treatment period, the rats were weighed, fasted overnight and anesthetized by exposure to chloroform. While under anesthesia, they were painlessly sacrificed and blood was collected from each rat into heparin sample bottles. Then their hearts, kidneys, liver and lungs were removed and their sizes immediately determined. The heparin anti-coagulated blood samples were centrifuged at $3000 \mathrm{rpm}$ for $10 \mathrm{~min}$, after which their plasma was collected and stored for subsequent analysis.

\subsubsection{Determination of Organ Sizes}

The sizes of lungs, kidney, heart and liver were determined by water displacement method, using eureka can. They were individually placed in the can, and the volume of water displaced was recorded as the size of the corresponding organ.

\subsubsection{Determination of the Plasma Lipid Profile and Atherogenic Indices}

Plasma triglyceride, total and high density lipoprotein cholesterol concentrations were assayed enzymatically with commercial test kits (Randox Laboratories Ltd., Crumlin, England). The concentration of the resultant quinoneimine (indicator), was determined at $546 \mathrm{~nm}$ (for triglyceride) and $540 \mathrm{~nm}$ (for total and high density lipoprotein cholesterol), using a spectrophotometer [Model 752S (Spectrumlab)].

Plasma very low density lipoprotein (VLDL)- and LDL-cholesterol were calculated using the Friedewald equation [27] as follows:

$$
\begin{aligned}
& \text { 1) }[\text { LDL cholesterol }](\mathrm{mmol} / \mathrm{L}) \\
& =[\text { Total cholesterol }]-[\text { HDL cholesterol }] \\
& -\frac{[\text { Triglyceride }]}{2.2}
\end{aligned}
$$

$$
\text { 2) }[\text { VLDL cholesterol }](\mathrm{mmol} / \mathrm{L})=\frac{[\text { Triglyceride }]}{2.2}
$$

Plasma nonHDL cholesterol content was computed as reported by Brunzell et al. [28]:

$$
\begin{aligned}
& \text { [NonHDL cholesterol }] \\
& =[\text { Total cholesterol }]-[\text { HDL cholesterol }]
\end{aligned}
$$

Atherogenic indices were computed with the following formulae [29]:

1) Cardiac risk ratio $=\frac{[\text { Total cholesterol }]}{[\text { HDL cholesterol }]}$

2) Atherogenic coefficient $=\frac{[\text { Total cholesterol }]-[\text { HDL cholesterol }]}{[\text { HDL cholesterol }]}$

3) Atherogenic index of plasma

$$
=\log \frac{[\text { Triglyceride }]}{[\text { HDL cholesterol }]}
$$

\subsection{Statistical Analysis of Data}

All values were reported as mean \pm standard deviation (s.d.). The values of the variables were analyzed for statistically significant differences using the Student's $t$-test, with the help of SPSS Statistics 17.0 package (SPSS Inc., Chicago Ill). $\mathrm{P}<0.05$ was assumed to be significant. Graphs were drawn using Microsoft Office Excel, 2010 software.

\section{Results}

\subsection{Phytochemical Profile}

Figures 2-5 show the chromatograms of the glycosides, saponins, allicins and alkaloids fractions of aqueous extract of leaves of Chromolaena odorata. Two known glycosides were detected, consisting of $99.98 \%$ arbutin and $0.02 \%$ salicin. Four known saponins were detected, consisting of $54.88 \%$ avenacin B-1, $45.07 \%$ avenacin A- $1,0.03 \%$ avenacin B-2 and $0.02 \%$ avenacin A-2. Three known allicins were detected, consisting of $90.78 \%$ diallyl thiosulphinate, $7.59 \%$ methylallyl thiosulphinate and $1.63 \%$ allyl methyl thiosulphinate. Thirty one known alkaloids were detected consisting of $64.74 \%$ lupanine, $18.60 \%$ augustamine, $5.21 \%$ augustifoline, $0.13 \%$ crinamidine, $0.06 \%$ caffeine, $0.03 \%$ indicine- $\mathrm{N}$-oxide, $0.03 \%$ sparteine, $0.03 \%$ ellipcine, $0.02 \%$ ambelline, $0.02 \%$ theophylline, $0.02 \%$ cinchonine, $0.02 \%$ crinane- $3 \alpha$-ol and $0.01 \%$ oxoassoamine.

Figures 6-8 show the chromatograms of the terpenes, benzoic acid derivatives and lignans fractions of aqueous extract of leaves of Chromolaena odorata. Twenty four terpenes were detected, consisting of $63.76 \%$ limonene, $6.52 \%$ geranyl acetate, $5.94 \%$ camphor, $4.39 \%$ 1,8- cineole, 3.04\% terpinen-4-ol, 2.22\% borneol acetate, 1.54\% neral, $1.35 \%$ borneol, $1.20 \% \beta$-pinene, $1.06 \%$ neryl acetate, $0.90 \%$ sabinene, $0.83 \%$ citronellol, $0.77 \%$ lupeol, $0.75 \%$ taraxeron, $0.75 \% \beta$-amyrin, $0.74 \% \alpha$-pinene, $0.72 \%$ $\alpha$-amyrin, $0.68 \% \alpha$-thujene, $0.63 \% \alpha$-terpineol, $0.57 \%$ allo ocimene, $0.55 \%$ camphene, $0.48 \%$ myrcene, $0.45 \%$ nerol (geraniol) and $0.16 \%$ cis ocimene. Nine benzoic 


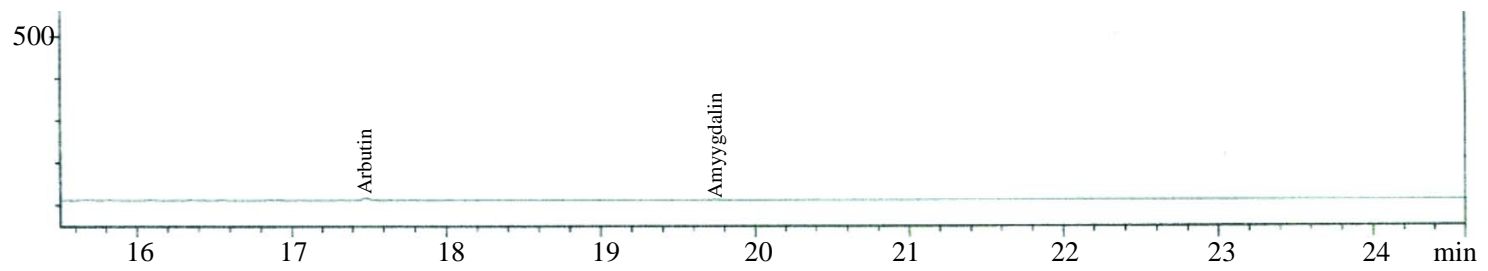

Figure 2. Chromatogram of the glycosides fraction of the aqueous extract of the leaves of Chromolaena odorata.

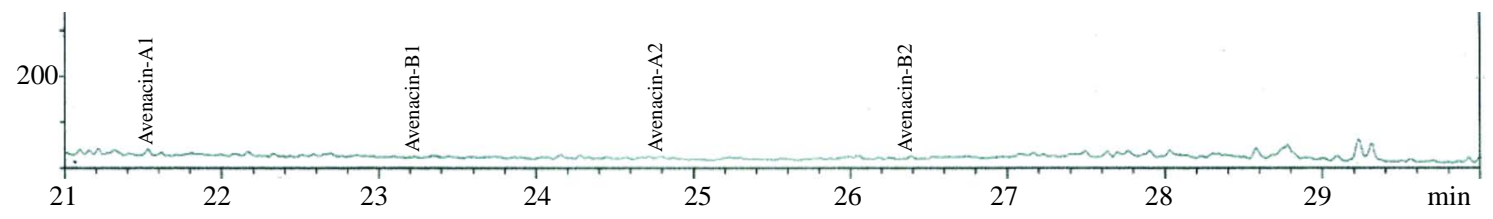

Figure 3. Chromatogram of the saponins fraction of the aqueous extract of the leaves of Chromolaena odorata.

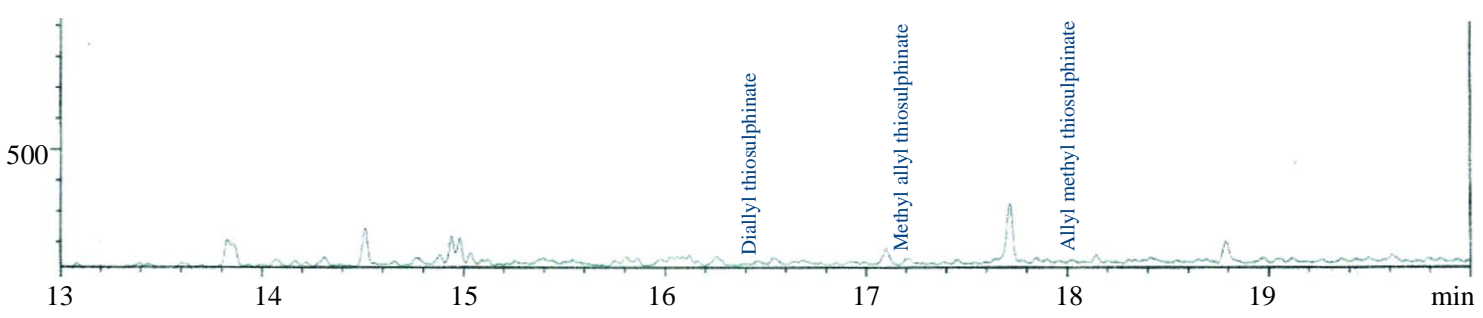

Figure 4. Chromatogram of the allicins fraction of the aqueous extract of the leaves of Chromolaena odorata.

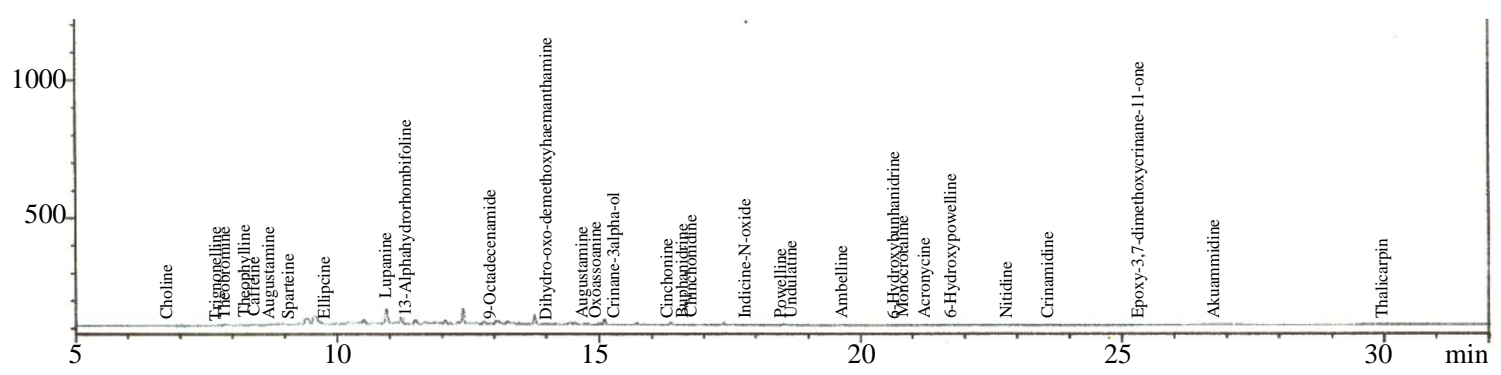

Figure 5. Chromatogram of the alkaloids fraction of the aqueous extract of the leaves of Chromolaena odorata.

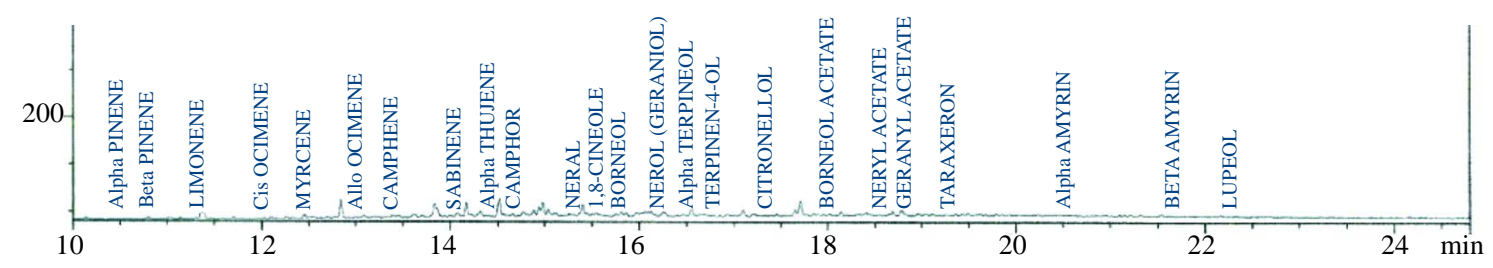

Figure 6. Chromatogram of the terpenes fraction of the aqueous extract of the leaves of Chromolaena odorata.

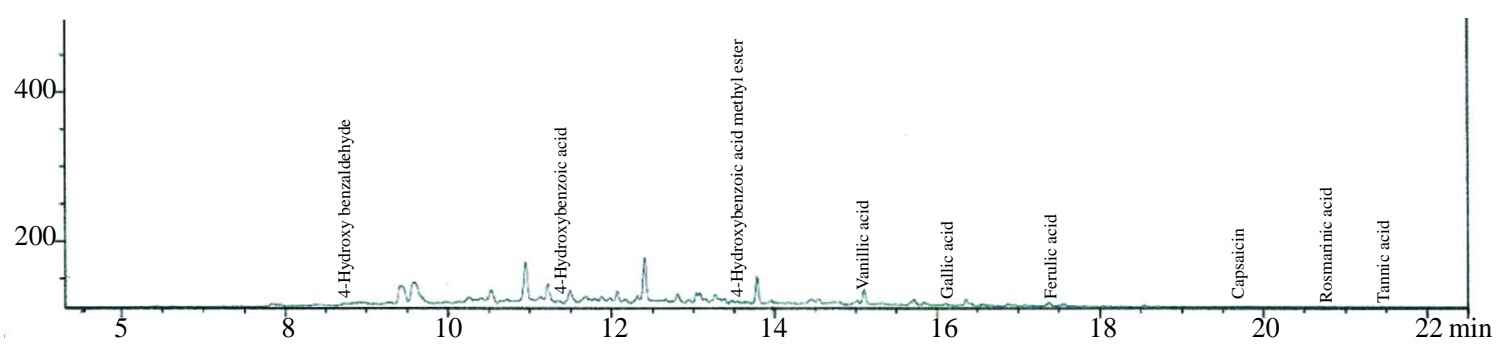

Figure 7. Chromatogram of the benzoic acid derivatives fraction of the aqueous extract of the leaves of Chromolaena odorata. 


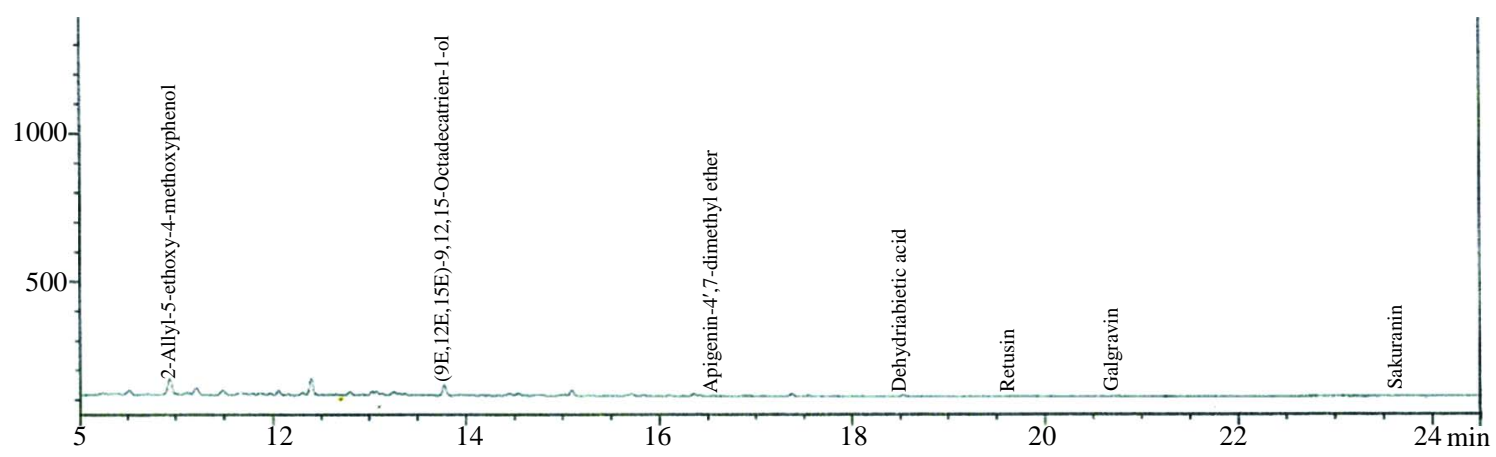

Figure 8. Chromatogram of the lignans fraction of the aqueous extract of the leaves of Chromolaena odorata.

acid derivatives were detected, consisting of $49.88 \%$ ferulic acid, 38.60\% vanillic acid, 5.01\% gallic acid, $4.08 \%$ 4-hydroxybenzoic acid, 0.83\% 4-hydroxybenzaldehyde, $0.83 \%$ capsaicin, $0.76 \%$ rosmarinic acid. Seven lignans were detected consisting of $88.86 \%$ retusin, $6.22 \%$ (9E, 12E, 15E)-9, 12, 15-octadecatrien-1-ol, 2.02\% 2-allyl-5ethoxy4-methoxyphenol, 1.67\% dehydroabietic acid, 0.84\% apigenin-4',7-dimethyl ether, $0.36 \%$ galgravin and $0.05 \%$ sakuranin.

\subsection{Effect on Body Weight and Organ Sizes}

The effect of aqueous extract of leaves of Chromolaena odorata on mean daily weight gain of normal and sub-chronic salt-loaded rats is given in Figure 9. The mean daily weight gain of the test control group was not significantly different from those of the other groups. Compared to the corresponding values before treatment, the reference was significantly higher $(\mathrm{P}<0.05)$, treatment control 2 was significantly lower $(\mathrm{P}<0.05)$, while the others were not significantly different. The effect of aqueous extract of leaves of Chromolaena odorata on organ sizes of normal and sub-chronic salt-loaded rats is given in Figure 10. The liver size of the test control group was significantly lower $(\mathrm{P}<0.05)$ than those of the normal and reference, and significantly higher $(\mathrm{P}<0.05)$ than that of treatment control 2, but not significantly different from those of treatment 1 , treatment 2 and treatment control 1. The kidney size of the test control group was significantly higher $(\mathrm{P}<0.05)$ than those of reference and treatment control 2, but not significantly different from those of normal, treatment 1, treatment 2 and treatment control 1 . The heart size of the test control group was significantly higher $(\mathrm{P}<0.05)$ than those of the other groups. The lung size of the test control group was not significantly different from those of the other groups.

\subsection{Effect on Plasma Lipid Profile and Indices}

The effect of aqueous extract of the leaves of Chromo- laena odorata on the plasma lipid profiles of normal and sub-chronic salt-loaded rats is present in Figure 11. The plasma triglyceride, total-, VLDL-, LDL- and non-HDL cholesterol levels of the test control group were significantly $(\mathrm{P}<0.05)$ higher than those of the other groups. The plasma HDL cholesterol level of the test control group was significantly $(\mathrm{P}<0.05)$ lower than those of the other groups. Figure 12 shows the effect of aqueous extract of leaves of Chromolaena odorata on the atherogenic indices of normal and sub-chronic salt-loaded rats. The atherogenic indices (cardiac risk ratio, atherogenic coefficient and atherogenic index of plasma) of the test control group were significantly $(\mathrm{P}<0.05)$ higher than those of the other groups.

\section{Discussion}

There is a direct relationship between the regression of left ventricular hypertrophy and a decreased risk of mortality [12]. Therefore, regression of cardiomegaly (left ventricular hypertrophy) or reversal of cardiac organ damage appears to be a primary goal in antihypertensive treatment [30,31]. In this study, the extract protected the treated animals against salt-loading induced increases in heart sizes. This may be one of the bases of its antihypertensive action, and is an indication of the cardio-protective potential of the extract.

Evidences from studies suggest that hypercholesterolemia contributes to the progression of hypertension through a number of possible mechanisms such as: low nitric oxide bioavailability, enhanced activity of the renin-angiotensin-aldosterone system, enhanced endothelin levels and receptor expression, endothelial dysfunction, salt sensitivity (which is aggravated by endothelial dysfunction), the secretion of vasoconstrictive molecules and an enrichment of cholesterol in cellular membranes, all of which reduce membrane fluidity and ion channel transporter activity [32]. Therefore, cholesterol lowering is a therapy that may potentially target arterial stiffness, and thus blood pressure, through effects on endothelial function and arterial wall composition [33]. In this study, 


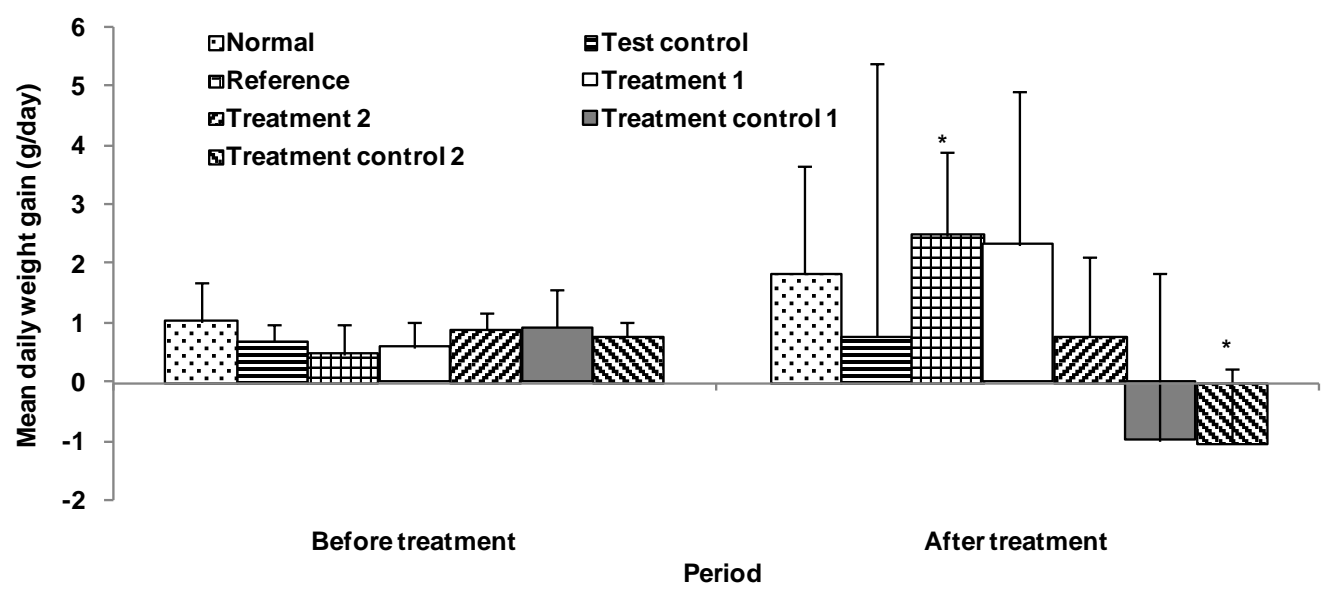

Figure 9. Effect of aqueous extract of the leaves of Chromolaena odorata on the mean daily weight gain of normal and sub-chronic salt-loaded rats. Values are mean \pm s.d., $n=5$, per group. $* P<0.05$ compared to the corresponding values before treatment.
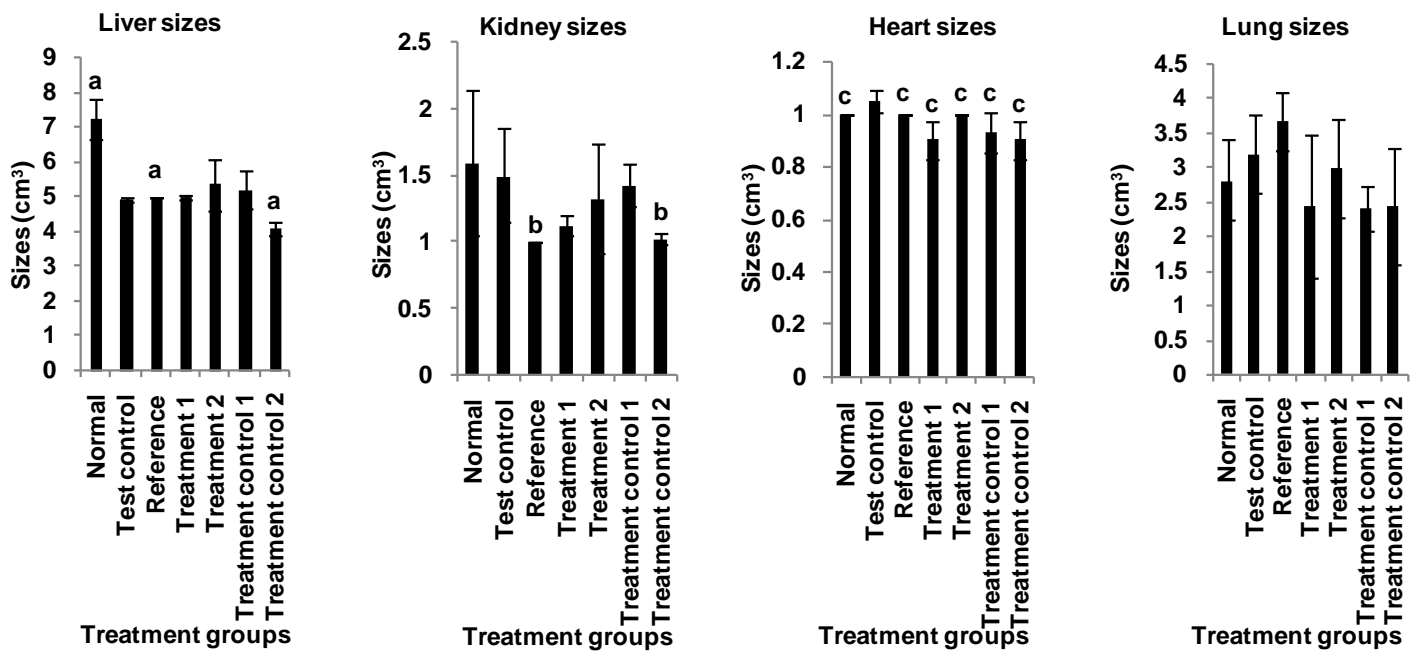

Figure 10. Effect of aqueous extract of the leaves of Chromolaena odorata on the organ sizes of normal and sub-chronic saltloaded rats. Values are mean \pm s.d., $n=5$, per group. ${ }^{a, b, c} \mathbf{P}<0.05$ compared to corresponding test control in the same block of columns.

the extract produced significantly lower plasma total cholesterol levels in the treated rats. This again, may be cardio-protective, since reduction in plasma total cholesterol levels have been reported to reduce the risk of cardiovascular disease [34]. This cholesterol lowering effect of the extract may have been mediated by its content of allicins, lignans and saponins [35-37], all of whom are known to have cholesterol lowering and atheroprotective activity. Thus, anyone or a combination of the above mentioned components could have been responsible for the hypocholesterolemic effect of the extract.

Studies have shown that reductions in plasma LDL and VLDL cholesterol reduce the risk of cardiovascular disease [38]. Therefore, the significantly lower plasma LDL and VLDL cholesterol levels observed in the ani- mals given the extract is another indication of its likely cardio-protective potential. This effect may have been due to the presence of lignans [39] and saponins [36], both of whom are known to reduce plasma LDL cholesterol.

The significantly lower plasma non-HDL cholesterol levels observed in the treated groups further underscores the ability of the extract to reduce cardiovascular risk. Recent evidence indicates that non-HDL cholesterol can better translate the risk of cardiovascular mortality than LDL-cholesterol [28], as it expresses more accurately the lipoprotein atherogenicity [40]. It reflects the total concentration of atherogenic particles, and is closely related to particle number [41].

The high plasma HDL cholesterol level, recorded for 


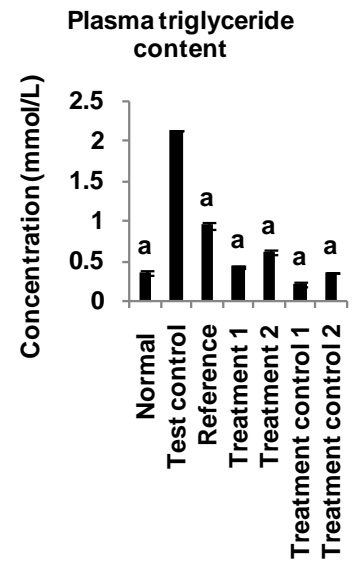

Treatment groups

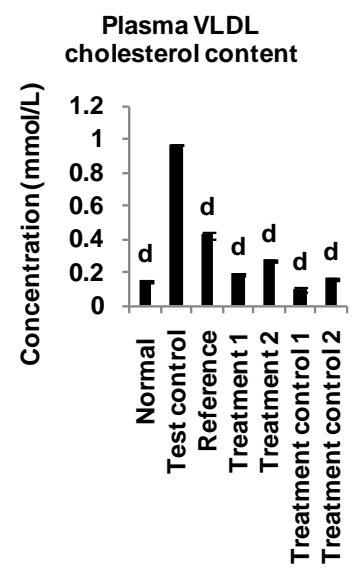

Treatment groups

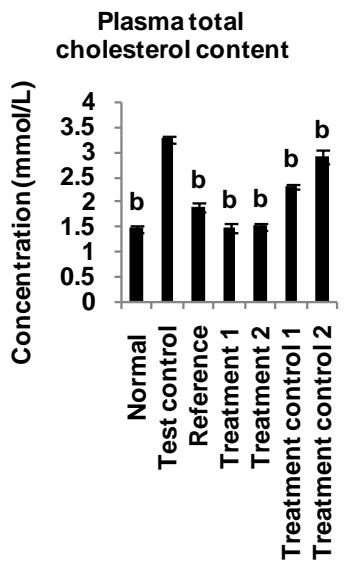

Treatment groups

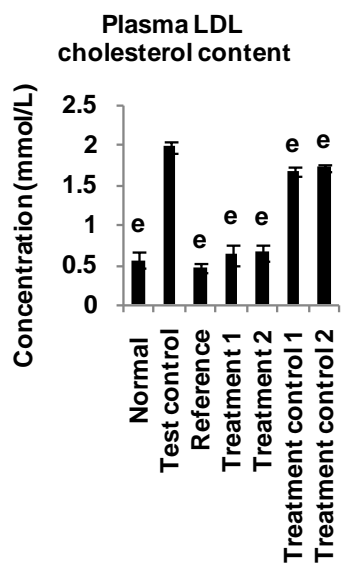

Treatment groups
Plasma HDL cholesterol content

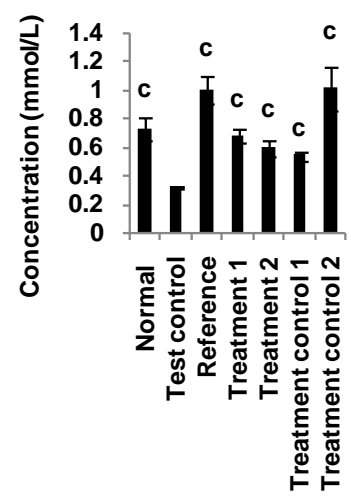

Treatment groups

Plasma non-HDL cholesterol content

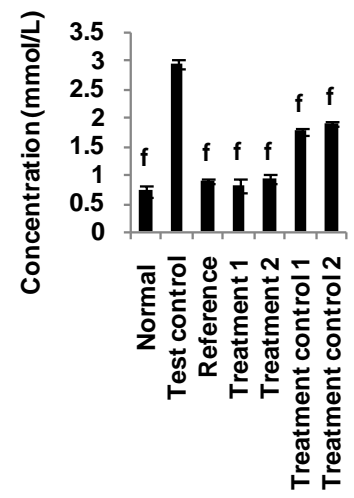

Treatment groups

Figure 11. Effect of aqueous extract of the leaves of Chromolaena odorata on the plasma lipid profile of normal and subchronic salt-loaded rats. HDL: high density lipoprotein; VLDL: very low density lipoprotein; LDL: low density lipoprotein. Values are mean \pm s.d., $n=5$, per group. ${ }^{a, b, c} \mathbf{P}<0.05$ compared to corresponding test control in the same block of columns.

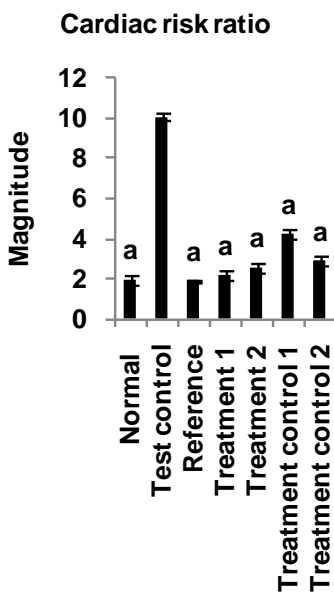

Treatment groups
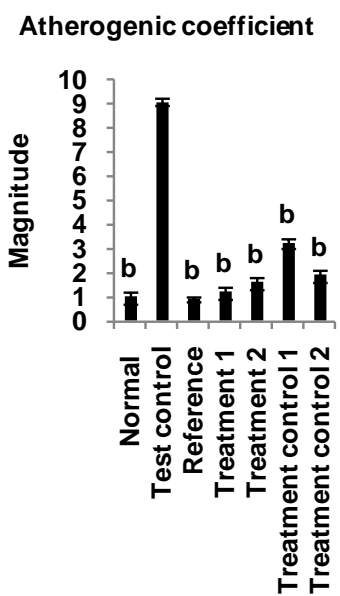

Treatment groups

$$
\begin{gathered}
\text { Atherogenic index } \\
\text { of plasma }
\end{gathered}
$$
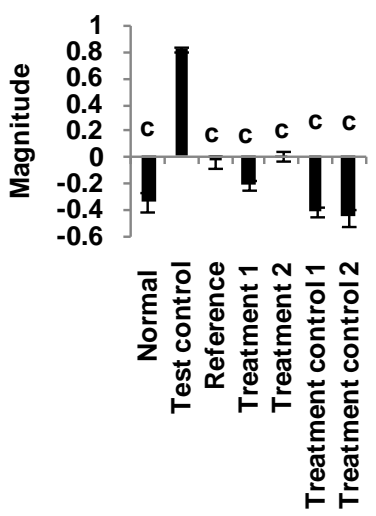

Treatment groups

Figure 12. Effect of aqueous extract of the leaves of Chromolaena odorata on the atherogenic indices of normal and subchronic salt-loaded rats. Values are mean \pm s.d., $n=5$, per group. ${ }^{\text {a,b,c }} \mathbf{P}<0.05$ compared to corresponding test control in the same block of columns. 
the treated groups, is indicative of the cardio-protective propensity of the extract. This is because increases in plasma HDL cholesterol is considered to reduce the risk of cardiovascular disease [42], probably via promotion of reverse cholesterol transport [43]; and inhibition of the oxidation of LDL, as well as the atherogenic effects of oxidized LDL by virtue of its antioxidant [44] and anti-inflammatory [45] properties. The elevation of plasma HDL cholesterol may have been mediated by lignans present in the extract [46].

The extract produced significantly lower plasma triglycerides levels in the treated rats. This suggests a likely cardio-protective potential of the extract, since reductions in plasma triglyceride levels have been reported to reduce cardiovascular risk [47]. This hypotriglyceridemic effect may have been produced by the lignans present in the extract [39].

In this study, the extract lowered all the atherogenic indices. This is also another indication of it cardio-protective propensity, since atherogenic indices are powerful predictors of positive findings in heart disease [48]. In fact, changes in these ratios have been shown to be better indicators of successful coronary heart disease risk reduction than changes in absolute levels of lipids or lipoproteins [40]. Reports have it that low atherogenic indices are protective against coronary heart disease, and that the risk of developing cardiovascular complications increases with the magnitude of the atherogenic index, and vice versa [49].

\section{Conclusion}

These results indicate a possible protective mechanism of the extract against hypertension induced cardiomegaly and dyslipidemia, thus suggesting that this may underlie its antihypertensive action. The therapeutic implication of this result to the management of hypertension cannot be overemphasized, especially in view of the reports that some commonly used antihypertensive drugs accentuate hyperlipidemia and have little or no effect on cardiomegaly.

\section{Acknowledgements}

We are grateful to Bello Atanda Akeem, the Managing Consultant of Multi Environmental Management Consultants Limited, for carrying out the phytochemical analysis in his laboratory.

\section{REFERENCES}

[1] G. Kabakci, N. Koylan, B. Ilerigelen, O. Kozan and K Buyukozturk, on Behalf of the ICEBERG Investigators, "Impact of Dyslipidemia on Cardiovascular Risk Stratification of Hypertensive Patients and Association of Lipid Profile with other Cardiovascular Risk Factors: Results from the ICEBERG Study," Integrated Blood Pressure
Control, Vol. 1, No. 1, 2008, pp. 5-13.

http://dx.doi.org/10.2147/IBPC.S3809

[2] Y. Zhao, C. Wang, J. Wu, Y. Wang, W. Zhu, Y. Zhang and Z. Du, "Choline Protects against Cardiac Hypertrophy Induced by Increased After-Load,” International Journal of Biological Science, Vol. 9, No. 3, 2013, pp. 295302. http://dx.doi.org/10.7150/ijbs.5976

[3] R. Kelishadi, "Dyslipidemia - from Prevention to Treatment,” InTech, Croatia, 2012.

http://www.intechopen.com/download/pdf/27502

[4] M. Vokurková, Z. Dobešová, J. Kuneš and J. Zicha, "Membrane Ion Transport in Erythrocytes of Salt Hypertensive Dahl Rats and Their F2 Hybrids: The Importance of Cholesterol," Hypertension Research, Vol. 26, No. 5, 2003, pp. 397-404. http://dx.doi.org/10.1291/hypres.26.397

[5] J. Zicha, Z. Dobešová, M. Vokurková, H. Rauchová, S. Hojná, M. Kadlecová, M. Behuliak, I. Vaněčková and J. Kuneš, "Age-Dependent Salt Hypertension in Dahl Rats: Fifty Years of Research,” Physiology Research, Vol. 61, No. Suppl. 1, 2012, pp. S35-S87.

http://www.biomed.cas.cz/physiolres/pdf/61\%20Suppl\%2 01/61_S35.pdf

[6] H. Bernardes-Silva, O. Toffoletto, L. A. Bortolotto, M. C. M. Latrilha, E. M. Krieger, F. Pileggi and R. C. Maranhão, "Malignant Hypertension Is Accompanied by Marked Alterations in Chylomicron Metabolism," Hypertension, Vol. 26, No. 6, 1995, pp. 1207-1210. http://dx.doi.org/10.1161/01.HYP.26.6.1207

[7] P. S. Sever, B. Dahlöf, N. R. Poulter, H. Wedel, G. Beevers, M. Caulfield, R. Collins, S. E. Kjeldsen, A. Kristinsson, G. T. McInnes, J. Mehlsen, M. Nieminen, E. O’Brien and J. Östergren, for the ASCOT Investigators, "Prevention of Coronary and Stroke Events with Atorvastatin in Hypertensive Patients Who Have Average or Lowerthan-Average Cholesterol Concentrations, in the AngloScandinavian Cardiac Outcomes Trial-Lipid Lowering Arm (ASCOT-LLA): A Multicentre Randomised Controlled Trial,” Lancet, Vol. 361, No. 9364, 2003, pp. 1149-1158.

http://dx.doi.org/10.1016/S0140-6736(03)12948-0

[8] J. B. Leikin and M. S. Lipsky, “American Medical Association Complete Medical Encyclopedia,” Random House Reference, New York, 2003.

[9] C. Ferreira Filho, L. C. de Abreu, V. E. Valenti, M. Ferreira, A. Meneghini, J. A. Silveira, A. R. Pérez Riera, E. Colombari, N. Murad, P. R. Santos-Silva, L. J. H. Pereira da Silva, L. C. M. Vanderlei, T. D. Carvalho and C. Ferreira, "Anti-Hypertensive Drugs Have Different Effects on Ventricular Hypertrophy Regression,” Clinics, Vol. 65, No. 7, 2010, pp. 723-728.

http://dx.doi.org/10.1590/S1807-59322010000700012

[10] K. Urbanek, F. Quaini, G. Tasca, D. Torella, C. Castaldo, B. Nadal-Ginard, A. Leri, J. Kajstura, E. Quaini and P. Anversa, "Intense Myocyte Formation from Cardiac Stem Cells in Human Cardiac Hypertrophy," Proceedings of the National Academy of Science USA, Vol. 100, No. 18, 2003, pp. 10440-10445.

http://dx.doi.org/10.1073/pnas.1832855100 
[11] E. A. Bregagnollo, K. Okoshi, I. F. Bregagnollo, C. R. Padovani, M. P. Okoshi and A. C. Cicogna, "Effects of the Prolonged Inhibition of the Angiotensin-Converting Enzyme on the Morphological and Functional Characteristics of Left Ventricular Hypertrophy in Rats with Persistent Pressure Overload," Arquivos Brasileiros de Cardiologia, Vol. 84, No. 3, 2005, pp. 225-232. http://dx.doi.org/10.1590/S0066-782X2005000300006

[12] P. Verdecchia, F. Angeli, P. Achilli, C. Castellani, A. Broccatelli, R. Gattobigio and C. Cavallini, "Echocardiographic Left Ventricular Hypertrophy in Hypertension: Marker for Future Events or Mediator of Events?" Current Opinions in Cardiology, Vol. 22, No. 4, 2007, pp. 329-334. doi:10.1097/HCO.0b013e328

[13] A. S. Wierzbicki, "Lipid Lowering: Another Method of Reducing Blood Pressure?” Journal of Human Hypertension, Vol. 16, No. 11, 2002, pp. 753-760. http://dx.doi.org/10.1038/sj.jhh.1001483

[14] M. Pandey, M. Debnath, S. Gupta and S. K. Chikara, "Phytomedicine: An Ancient Approach Turning into Future Potential Source of Therapeutics," Journal of Pharmacognosy and Phytotherapy, Vol. 3, No. 3, 2011, pp. 27-37.

http://www.academicjournals.org/jpp/PDF/Pdf2011/Marc $\underline{\text { h/Pandey\%20et\%20al.pdf }}$

[15] P. Juretschke, W. F. Vogel and G. Riess, "Strategies in Drug Discovery and Evaluation,” In: H. G. Vogel, Ed., Drug Discovery and Evaluation: Pharmacological Assays, 3rd Edition, Springer-Verlag, New York, 2008, pp. 1-45. http://www.springer.com/cda/content/document/cda_dow nloaddocument/9783540423966-t1.pdf

[16] M. T. Yakubu, "Effect of a 60-Day Oral Gavage of a Crude Alkaloid Extract from Chromolaena odorata Leaves on Hormonal and Spermatogenic Indices of Male Rats,” Journal of Andrology, Vol. 33, No. 6, 2012, pp. 1199-1207. http://dx.doi.org/10.2164/jandrol.111.016287

[17] The State of Queensland, Department of Agriculture, Fisheries and Forestry, "Siam Weed (Chromolaena odorata), Declared Class 1 Pest Plant,” Fact Sheet PP49, Department of Agriculture, Fisheries and Forestry Biosecurity Queensland, 2013. http://www.daff.qld.gov.au/_data/assets/pdf_file/0015/5 0028/IPA-Siam-Weed-PP49.pdf

[18] J. C. Ikewuchi, C. C. Ikewuchi, E. C. Enuneku, S. A. Ihunwo, O. I. Osayande, D. B. Batubo and D. I. D. Manuel, "Alteration of Blood Pressure Indices and Pulse Rates by an Aqueous Extract of the Leaves of Chromolaena odorata (L) King and Robinson (Asteraceae)," Pacific Journal of Science and Technology, Vol. 13, No. 2, 2012, pp. 348-358.

http://www.akamaiuniversity.us/PJST13_2_348.pdf

[19] O. O. Oluwaniyi and S. A. Ibiyemi, "A Study of the Extractability of Thevetia Glycosides with Alcohol Mixture," Journal of Food Technology, Vol. 5, No. 2, 2007, pp. 147-151.

http://docsdrive.com/pdfs/medwelljournals/jftech/2007/14 7-151.pdf

[20] M. Guo, L. Zhang and Z. Liu, “Analysis of Saponins from Leaves of Aralia elata by Liquid Chromatography and Multi-stage Tandem Mass Spectrometry,” Analytical Science, Vol. 25, No. 6, 2009, pp. 753-758. http://dx.doi.org/10.2116/analsci.25.753

[21] J. Roy, D. M. Shakleya, P. S. Callery and J. G. Thomas, "Chemical Constituents and Antimicrobial Activity of a Traditional Herbal Medicine Containing Garlic and Black Cumin," African Journal of Traditional, Complementary and Alternative Medicines, Vol. 3, No. 2, 2006, pp. 1-7. http://dx.doi.org/10.4314/ajtcam.v3i2.31151

[22] N. T. C. Tram, M. Mitova, V. Bankova, N. Handjieva and S. S. Popov, "GC-MS of Crinum latifolium L. Alkaloids," Zeitschrift für Naturforschung, Vol. 57c, 2002, pp. 239242. http://www.znaturforsch.com/ac/v57c/s57c0239.pdf

[23] A. Ortan, M.-L. Popescu, A.-L. Gaita, C. Dinu-Pîrvu and G. H. Câmpeanu, "Contributions to the Pharmacognostical Study on Anethum graveolens, Dill (Apiaceae)," Romanian Biotechnological Letters, Vol. 14, No. 2, 2009, pp. 4342-4348. http://www.rombio.eu/rbl2vol14/cnt/Lucr-18.pdf

[24] D. O. Ndoumou, G. T. Ndzomo and P. F. Djocgoue, "Changes in Carbohydrate, Amino Acid and Phenol Contents in Cocoa Pods from three Clones after Infection with Phytophthora megakarya Bra. and Grif," Annals of Botany, Vol. 77, No. 2, 1996, pp. 153-158. http://dx.doi.org/10.1006/anbo.1996.0017

[25] J. M. Chapman, C. Knoy, K. Kindscher, R. C. D. Brown and S. Niemann, "Identification of Antineoplastic and Neurotrophic Lignans in Medicinal Prairie Plants by Liquid Chromatography Electron Impact Mass Spectrometry (LC/EI/MS),” Life Sciences, 2006.

http://www.cssco.com/files/KC\%20Life\%20Science\%20 2006.pdf

[26] P. C. M. Obiefuna, O. A. Sofola and A. B. Ebeigbe, "Dietary Salt-Loading Attenuates Endothelium Dependent Relaxation in Response to Histamine but Not to Acetylcholine in Rat Aortic Rings,” Experimental Physiology, Vol. 76, No. 1, 1991, pp. 135-138. http://ep.physoc.org/content/76/1/135.long

[27] W. T. Friedewald, R. I. Levy and D. S. Friedrickson, "Estimation of the Concentration of Low-Density Lipoprotein Cholesterol in Plasma, without Use of the Preparative Ultracentrifuge," Clinical Chemistry, Vol. 18, No. 6, 1972, pp. 499-502. http://www.clinchem.org/content/18/6/499.full.pdf

[28] J. D. Brunzell, M. Davidson, C. D. Furberg, R. D. Goldberg, B. V. Howard, J. H. Stein and J. L. Witztum, "Lipoprotein Management in Patients with Cardiometabolic Risk: Consensus Conference Report from the American Diabetes Association and the American College of Cardiology Foundation," Journal of the American College of Cardiology, Vol. 51, No. 15, 2008, pp. 1512-1524. http://dx.doi.org/10.1016/j.jacc.2008.02.034

[29] J. C. Ikewuchi, E. N. Onyeike, A. A. Uwakwe and C. C. Ikewuchi, "Effect of Aqueous Extract of the Leaves of Acalypha wilkesiana 'Godseffiana' Muell Arg (Euphorbiaceae) on the Hematology, Plasma Biochemistry and Ocular Indices of Oxidative Stress in Alloxan Induced Diabetic Rats,” Journal of Ethnopharmacology, Vol. 137, No. 3, 2011, pp. 1415-1424. 
http://dx.doi.org/10.1016/j.jep.2011.08.015

[30] C. G. Brilla, "Regression of Myocardial Fibrosis in Hypertensive Heart Disease: Diverse Effects of Various Antihypertensive Drugs," Cardiovascular Research, Vol. 46, No. 2, 2000, pp. 324-331.

http://dx.doi.org/10.1016/S0008-6363(99)00432-0

[31] P. A. Van Zwieten, “The Influence of Antihypertensive Drug Treatment on the Prevention and Regression of Left Ventricular Hypertrophy," Cardiovascular Research, Vol. 45, No. 1, 2000, pp. 82-91. http://dx.doi.org/10.1016/S0008-6363(99)00291-6

[32] A. C. Sposito, "Emerging Insights into Hypertension and Dyslipidaemia Synergies,” European Heart Journal, Vol. 6, Suppl. G, 2004, pp. G8-G12. http://dx.doi.org/10.1016/j.ehjsup.2004.10.003

[33] K. E. Ferrier, M. H. Muhlmann, J. P. Baguet, J. D. Cameron, G. L. Jennings, A. M. Dart and B. A. Kingwell, "Intensive Cholesterol Reduction Lowers Blood Pressure and Large Artery Stiffness in Isolated Systolic Hypertension,” Journal of the American College of Cardiology, Vol. 39, No. 6, 2002, pp. 1020-1025.

[34] Scottish Intercollegiate Guidelines Network, "Risk Estimation and the Prevention of Cardiovascular Disease. A National Clinical Guideline,” Scottish Intercollegiate Guidelines Network, Edinburgh, 2007. http://www.sign.ac.uk/pdf/sign97.pdf

[35] J. L. Adolphe, S. J. Whiting, B. H. J. Juurlink, L. U. Thorpe and J. Alcorn, "Health Effects with Consumption of the Flax Lignan Secoisolariciresinol Diglucoside,” British Journal of Nutrition, Vol. 103, No. 7, 2010, pp. 929-938. http://dx.doi.org/10.1017/S0007114509992753

[36] G. Francis, Z. Kerem, H. P. S. Makkar and K. Becker, "The Biological Action of Saponins in Animal Systems: A Review,” British Journal of Nutrition, Vol. 88, No. 6, 2002, pp. 587-605. http://dx.doi.org/10.1079/BJN2002725

[37] L. D. Lawson, "Duration of the Hypocholesterolemic Effect of Garlic Supplements," JAMA Internal Medicine, Vol. 161, No. 20, 2001, pp. 2505-2506.

http://archinte.jamanetwork.com/article.aspx?articleid=64 $\underline{9365}$

[38] H. P. Rang, M. M. Dale, J. M. Ritter and P. K. Moore, "Pharmacology," 5th Edition, Elsevier, New Delhi, 2005.

[39] E. F. Al-Jumaily and Z. A. Auokty, "Reduction of Serum Hypercholesterolenic in Male Rabbits by Secoisolariciresinol Diglucoside (Lignan) Isolated from Flaxseed,” Trends in Life Sciences, Vol. 1, No. 1, 2012, pp. 6-11. http://sciencejournal.in/data/documents/TLS-1-2.pdf

[40] T. Pereira, "Dyslipidemia and Cardiovascular Risk: Lipid Ratios as Risk Factors for Cardiovascular Disease,” In: R. Kelishadi, Ed., Dyslipidemia-From Prevention to Treatment, InTech, Rijeka, 2012, pp. 279-302.

http://www.intechopen.com/download/pdf/27502 http://dx.doi.org/10.5772/1182

[41] P. Greenland, J. S. Alpert, G. A. Beller, E. J. Benjamin, M. J. Budoff, Z. A. Fayad, E. Foster, M. A. Hlatky, J. M. Hodgson, F. G. Kushner, M. S. Lauer, L. J. Shaw, S. C. Smith Jr., A. J. Taylor, W. S. Weintraub, N. K. Wenger,
A. K. Jacobs, S. C. Smith Jr., J. L. Anderson, N. Albert, C. E. Buller, M. A. Creager, S. M. Ettinger, R. A. Guyton, J. L. Halperin, J. S. Hochman, F. G. Kushner, R. Nishimura, E. M. Ohman, R. L. Page, W. G. Stevenson, L. G. Tarkington, C. W. Yancy and American College of Cardiology Foundation, American Heart Association, "2010 ACCF/AHA Guideline for Assessment of Cardiovascular Risk in Asymptomatic Adults: A Report of the American College of Cardiology Foundation/American Heart Association Task Force on Practice Guidelines," Circulation, Vol. 122, No. 25, 2010, pp. e584-e636.

http://dx.doi.org/10.1161/CIR.0b013e3182051b4c or http://circ.ahajournals.org/content/122/25/e584

[42] World Health Organization, "Prevention of Cardiovascular Disease. Guidelines for Assessment and Management of Cardiovascular Risk,” WHO Press, World Health Organization, Geneva, 2007.

http://whqlibdoc.who.int/publications/2007/97892415471 78_eng.pdf

[43] G. Assmann and A. M. Gotto Jr., "HDL Cholesterol and Protective Factors in Atherosclerosis," Circulation, Vol. 109, Suppl. III, 2004, pp. III-8-III-14. http://dx.doi.org/10.1161/01.CIR.0000131512.50667.46

[44] D. McGrowder, C. Riley, E. Y. S. A. Morrison and L. Gordon, "The Role of High-Density Lipoproteins in Reducing the Risk of Vascular Diseases, Neurogenerative Disorders, and Cancer," Cholesterol, Vol. 2011, 2001, Article ID: 496925.

http://dx.doi.org/10.1155/2011/496925

[45] V. Zannis, A. Kateifides, P. Fotakis, E. Zanni and D. Kardassis, "Pleiotropic Functions of HDL Lead to Protection from Atherosclerosis and Other Diseases,” In: R. Kelishadi, Ed., Dyslipidemia-From Prevention to Treatment, InTech, Rijeka, 2012, pp. 172-198.

http://www.intechopen.com/download/pdf/27503

[46] K. Prasad, "Hypocholesterolemic and Antiatherosclerotic Effect of Flax Lignan Complex Isolated from Flaxseed," Atherosclerosis, Vol. 179, No. 2, 2005, pp. 269-275. http://dx.doi.org/10.1016/j.atherosclerosis.2004.11.012

[47] M. Miller, N. J. Stone, C. Ballantyne, V. Bittner, M. H. Criqui, H. N. Ginsberg, A. C. Goldberg, W. J. Howard, M. S. Jacobson, P. M. Kris-Etherton, T. A. Lennie, M. Levi, T. Mazzone and S. Pennathur, "Triglycerides and Cardiovascular Disease: A Scientific Statement from the American Heart Association," Circulation, Vol. 123, No. 20, 2011, pp. 2292-2333.

http://dx.doi.org/10.1161/CIR.0b013e3182160726

[48] J. Frohlich and M. Dobiásová, "Fractional Esterification Rate of Cholesterol and Ratio of Triglycerides to HDLCholesterol Are Powerful Predictors of Positive Findings on Coronary Angiography," Clinical Chemistry, Vol. 49, No. 11, 2003, pp. 1873-1880. http://dx.doi.org/10.1373/clinchem.2003.022558

[49] M. Dobiásová, “Atherogenic Index of Plasma [Log (Triglyceride/HDL-Cholesterol)]: Theoretical and Practical Implications,” Clinical Chemistry, Vol. 50, No. 7, 2004, pp. 1113-1115.

http://dx.doi.org/10.1373/clinchem.2004.033175 